\title{
INCIDENCE, ABUNDANCE AND DAMAGE OF PAPAYA MEALYBUG IN SOUTHERN PART OF BANGLADESH AND ITS MANAGEMENT
}

\author{
M. M. H. KHAN AND M. N. HOSSAIN \\ Department of Entomology, Patuakhali Science and Technology University, \\ Dumki, Patuakhali, Bangladesh
}

\begin{abstract}
The papaya mealybug, Paracoccus marginatus Williams and Granara de Willink, is a small hemipteran that attacks several genera of host plants, including economically important tropical fruits and ornamentals. A study was carried out at farmers' papaya garden and homestead areas of 8 locations viz., Dumki, Bouphal, Dashmina, Patuakhali, Mirjagonj, Amtali, Kalapara and Kuakata of Patuakhali and Barguna districts of Bangladesh to observe the incidence, abundance, and damage potential of papaya mealybug, Paracoccus marginatus (Williams and Granara de Willink) from March to June 2019. An experiment consisting of seven treatments following randomized complete block design (RCBD) with three replications was conducted for controlling papaya mealybugs at Patuakhali Science and Technology University (PSTU) campus during March to June 2019. Results revealed that among 8 locations, the highest incidence of $P$. marginatus was recorded in June, and the lowest was in April. The maximum abundance of $P$. marginatus on leaves and fruits of the papaya plant was observed at Kolapara, and the lowest was at Amtali. The highest percent infested plants $(65 \%)$ per location, infested leaves/plant (97\%), and infested fruits/plant (47\%) was recorded in Kolapara, and the lowest percent infestations $(31,18$, and $11 \%$, respectively) were in Amtali. Among all treatments, the removal of infested leaves with petioles and application of Nitro 505EC @ $1 \mathrm{ml} / \mathrm{L}$ of water $\left(\mathrm{T}_{1}\right)$ was the best approach for the management of papaya mealybugs. The removal of infested leaves with petioles + Biotap plus extra 95EC @ 0.2 g/L of water $\left(\mathrm{T}_{3}\right)$ could be used as $2^{\text {nd }}$ choice for controlling papaya mealybugs. The results concluded that removal of infested leaves and the application of Nitro $505 \mathrm{EC}$ at the rate of $1 \mathrm{ml} / \mathrm{L}$ of water might be used to control the papaya mealybug.
\end{abstract}

Keywords: Abundance, Incidence, Mealybugs, Papaya, Paracoccus marginatus

\section{Introduction}

The papaya mealybug, Paracoccus marginatus Williams and Granara de Willink (Hemiptera: Pseudococcidae) is a small polyphagous sucking insect pest and has a wide host range that attacks several genera of plant species, including many economically important vegetables, fruit, and ornamental plants, such as avocado, beans, cassava, citrus,

*Corresponding author: E-mail: <mohasin1965@pstu.ac.bd> 
coffee, cotton, eggplant, frangipani, gardenia, hibiscus, mango, papaya, pea, sweet potato, tomato, and numerous weeds (Chellanppan et al., 2013; Cham et al. 2011; Tanwar et al., 2010; Miller and Miller 2002). A total of 50 plants species in 20 families were identified as the host of P. marginatus in Ghana in 2009 (Cham et al. 2011). Fourteen species of mealybugs were recorded in Bangladesh and attacked 103 host plants (Islam et al. 2017). $P$. marginatus is an invasive insect pest most probably believed to be native to Mexico or Central America (Tanwar et al. 2010; CABI, 2015). Walker et al. (2003) stated that $P$. marginatus was recorded from the 14 Caribbean countries. It has been reported to cause severe damages to horticultural and field crops (Muniappan et al., 2008; Tanwar et al. 2010). Though it is a severe pest of papaya (Tanwar et al., 2010; Bhawane et al., 2011; Chellanppan et al. 2013) and have also reported in guava (Sakthivel et al. 2012), mulberry (Tanwar et al. 2010; Lalitha et al. 2015) as a host of papaya mealybug, $P$. marginatus in India. Population abundance is the number of individuals per unit area/plant where the number of organisms in a population changes over time due to various factors such as birth, death, immigration, and emigration (Norris et al. 2003). The abundance of insect populations is also governed by the availability of food resources (Borror and DeLong 1954). Papaya mealybug is most active in warm and temperature weather and the infestation appears on above ground parts on leaves, stems, and fruits as clusters of cotton-like masses with long waxy filaments. The immature and adult stages of $P$. marginatus suck the sap by inserting its stylets into the epidermis of the leaf, fruit, and stem and weaken it. While feeding, it injects a toxic substance into the leaves, resulting in chlorosis, plant stunting, leaves becoming crinkled, yellowish and withered causing early leaf and fruit drop, and ultimately death of plants. The honeydew excreted by the bug results in the formation of a black sooty mould which interferes in the photosynthesis process and causes further damage to the crops. Heavy infestations can render fruit inedible due to the buildup of thick white waxy coating (Tanwar et al. 2010).

Mealybugs can be controlled by removing mealybugs by rubbing or picking mealybugs from affected plants which is practicable in a low infestation. Pruning and destroying affected plant parts is particularly useful at the initial stage of infestation (Schulthess et al. 1997; Neuenschwander 2003). Satyanarayana et al. (2003) found that phosphamidon was significantly superior over the rest of the treatments, recording $80 \%$ mortality. Among the extracts, the highest percentage (68.50\%) mortality was recorded from Azadirachta indica (Juss.) and the lowest (9.00\%) from Eucalyptus citridiora Hook. Tanwar et al. (2010) worked on the incidence and damaging value of papaya mealybug and its management strategies. Recently papaya mealybug has become a serious problem for the production of healthy papaya and its yield reduction in the southern coastal region 
of Bangladesh. So far, incidence and damages to papaya crops caused by P. marginatus in the southern part of Bangladesh have not yet been reported. Keeping this in view, studies were undertaken to monitor P. marginatus infestation on papaya in eight selected locations to know the incidence, abundance, and damage potential of papaya mealybug and find out suitable management approach against this papaya mealybug.

\section{Methodology}

Survey on the incidence, abundance and damage potential of mealybug on papaya: Studies were carried out in the farmers' field and homestead garden of Patuakhali and Barguna districts to collect data on the incidence, abundance and damage symptoms of mealybugs infesting papaya from September 2018 to June 2019. Eight locations viz., Dumki, Bouphal, Dashmina, Patuakhali, Mirjagonj, Amtali, Kalapara, and Kuakata were selected. Two villages from each location were selected considering papaya cultivation. A total of 80 plants taking five (5) papaya plants from each village were selected randomly. All the plant parts were carefully observed and recorded papaya mealybug population, its infestation and damage symptoms. The random selection and collection method was followed for the study providing every sampling unit an equal chance to be chosen. Every leaf was considered as a single sampling unit and a total of six leaves along with their twigs (two leaves each from lower, middle, and upper canopy) were sampled from randomly selected plants. Five plants were sampled randomly and considered as five replications from each location to avoid any errors. The leaves were cut with a sharp knife, placed in plastic sealed carry bags, and labeled with the date and locality of the collection. The samples thus collected were brought to the Entomology laboratory for sorting and population counts for mealybug for each plant. Later on these specimens were kept in glass jars and covered with muslin cloth on top for rearing the mealybug and were observed the presence of any natural enemies emerging from such infested specimens. Data on the number of infested and healthy plants per location, number of infested leaves per plant, number of fruits per plant were recorded through observation of individual plants in each location. Population abundance of $P$. marginatus

was measured by counting the number of egg and immature groups under a stereo microscope. 
Percentage of $P$. marginatus on the fruits and leaves was calculated by dividing the number of fruits/leaves attacked by the total number of fruits/leaves in each plant individual by:

$$
\mathrm{P}=\frac{\mathrm{n}}{\mathrm{N}} \times 1000
$$

with $\mathrm{P}=$ percentage attack rate, $\mathrm{n}=$ number of infested fruits/leaves per plant, and $\mathrm{N}=$ total number of fruits/leaves per plant.

Effect of some control approaches for managing mealybug on papaya: An experiment was laid out in a randomized complete block design with 3 replications. Seven treatments viz., $\mathrm{T}_{1}=$ Removal of infested leaves with petioles + application of Nitro 505EC @ 1 $\mathrm{ml} / \mathrm{L}$ of water, $\mathrm{T}_{2}=$ Application of Nitro 505EC @ $1 \mathrm{ml} / \mathrm{L}$ of water, $\mathrm{T}_{3}=$ Removal of infested leaves with petioles + Biotap plus extra 95EC @ $0.2 \mathrm{~g} / \mathrm{L}$ of water, $\mathrm{T}_{4}=$ Biotap plus extra 95EC @ $0.2 \mathrm{~g} / \mathrm{L}$ of water, $\mathrm{T}_{5}=$ Removal of infested leaves with petioles + application of voliam flexi 300SC @ $0.5 \mathrm{ml} / \mathrm{L}$ of water, $\mathrm{T}_{6}=$ Application of voliam flexi 300SC@0.5 ml/L of water and $\mathrm{T}_{7}=$ Untreated Control were used. Data were collected on the number of mealybugs per plant, leaf and fruit, the number of infested leaves and fruits/plant.

Data were analyzed by using WASP software following analysis of variance (ANOVA) and means were separated by $\mathrm{CD}$ (critical difference) values.

\section{Results and Discussion}

Damage symptoms: P. marginatus has only been recorded feeding on above-ground parts of its hosts, particularly on leaves and fruit. Papaya mealybug infestations are typically observed as clusters of cotton-like masses on the above-ground portion of plants. The papaya mealybug feeds on the sap of plants by inserting its stylets into the epidermis of the leaf, as well as into the fruit and stem. In doing so, it injects a toxic substance into the leaves. The result is chlorosis, plant stunting, leaf deformation, early leaf and fruit drop, a heavy honeydew building and death. Heavy infestations can render fruit inedible due to the buildup of thick white wax. The adult female is yellow and is covered with a white waxy coating. Heavy infestations by $P$. marginatus cause deformation of new growth, leaf yellowing, leaf curl and early fall of fruit. Fruit may become entirely covered by a layer of mealybugs and wax secretions (Plate 1). 


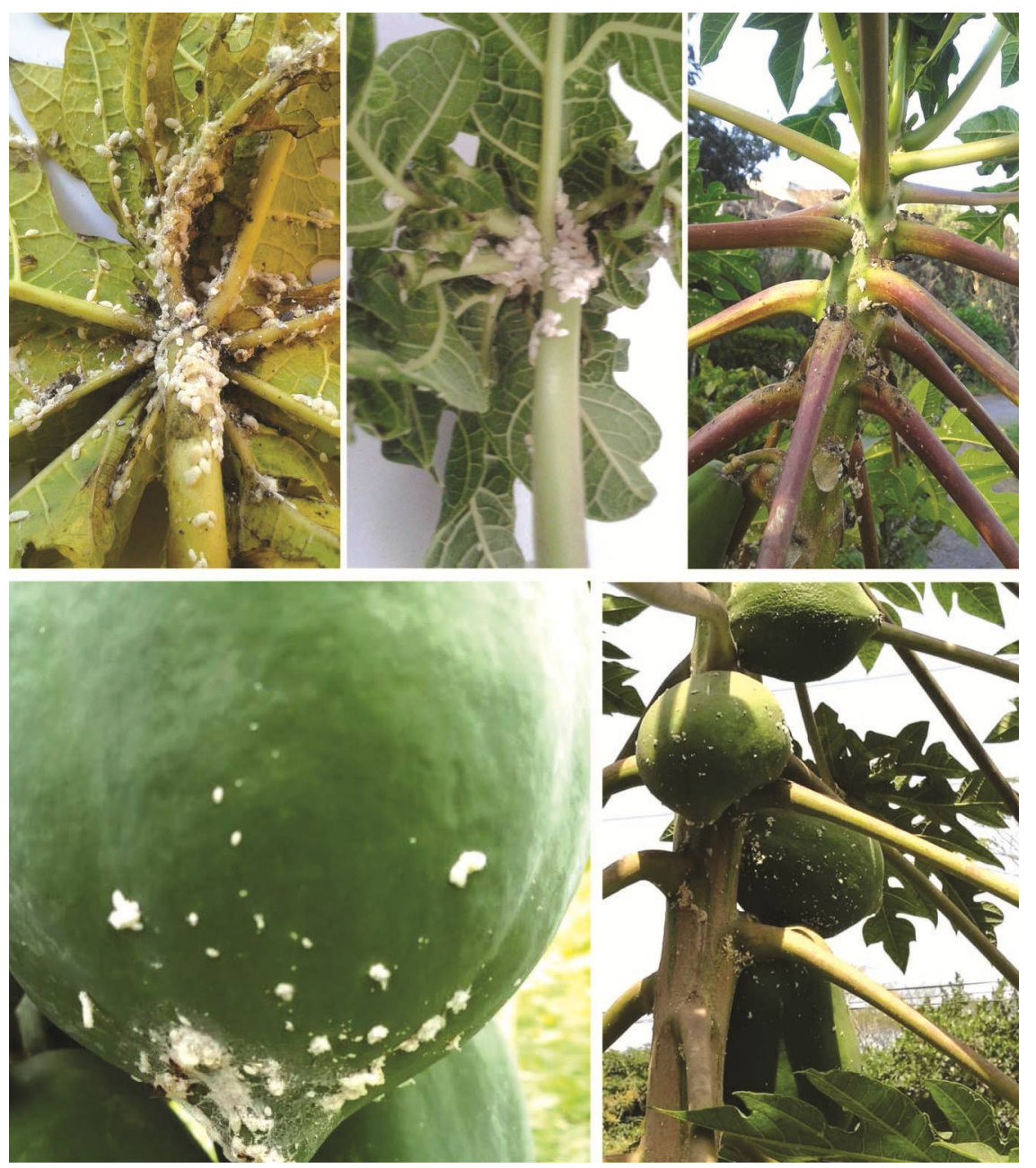

Plate 1. Infestation and damage symptoms of $P$. marginatus on different parts of papaya plant at PSTU campus.

Incidence of the mealybug population: The incidence of the mealybug population (P. marginatus) per leaf of papaya plant on various dates of observations is shown in Fig. 1. The highest incidence of mealybugs per leaf was observed on 24 June followed by 10 June and 27 May, while the lowest incidence was on 15 April, followed by 29 April and 13 May. The incidence of mealybugs gradually increased with increasing temperature and time. 


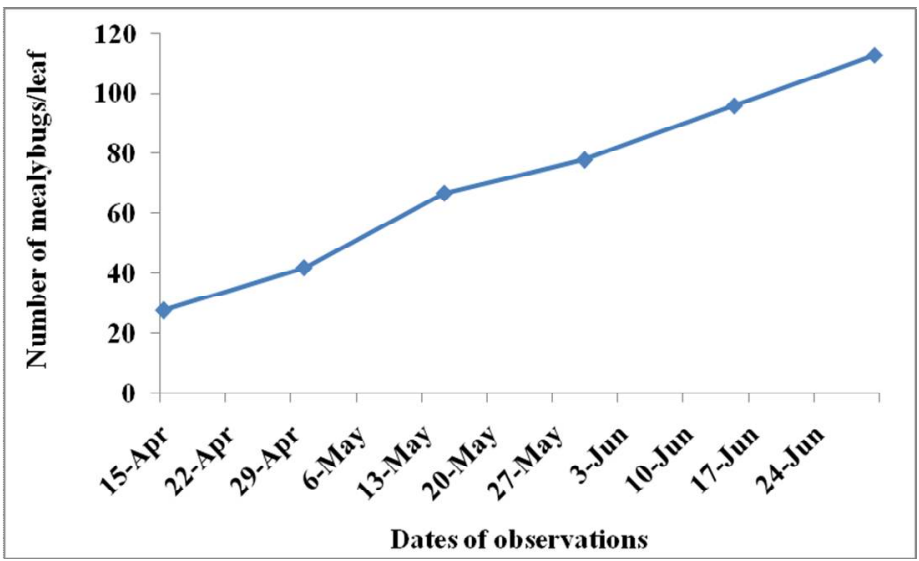

Fig. 1. Incidence of mealybug population (Paracoccus marginatus) per leaf of papaya plant at dumki upazila.

Abundance of $P$. marginatus on leaf and fruit of papaya plant: In the case of leaf, the highest number of papaya mealybugs was recorded in Kolapara (128 mealybugs/leaf), followed by Dumki (108), Dasmina (94), Bouphal (88) and Patuakhali (76) while the lowest number was at Amtali (42) followed by Kuakata (57) and Mirjaganj (61) (Fig. 2). A similar trend was also observed in the case of fruit where the highest number of mealybugs per fruit was recorded in Kolapara (82 mealybugs/fruit) followed by Dumki (73), Dasmina (62), and Bouphal (56), while the lowest number was in Amtali (28) followed by Kuakata (36), Mirjaganj (44) and Patuakhali (48) (Fig. 2).

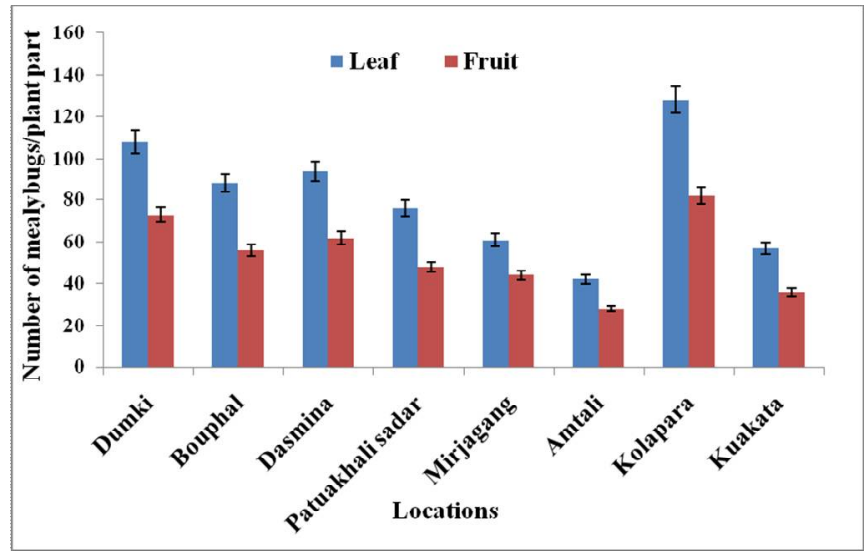

Fig. 2. Population abundance of $P$. marginatus on leaf and fruit of papaya plant in eight locations during April to June 2019. 
Percentage of plant infestation by P. marginatus: The percentage of plant infestation by $P$. marginatus in 8 locations is presented in Fig. 3. It revealed that the highest percent $(65 \%)$ infested plants per location was recorded in Kolapara followed by Dumki (58\%), while the lowest percent (31\%) was recorded at Amtali followed by Kuakata (36\%).

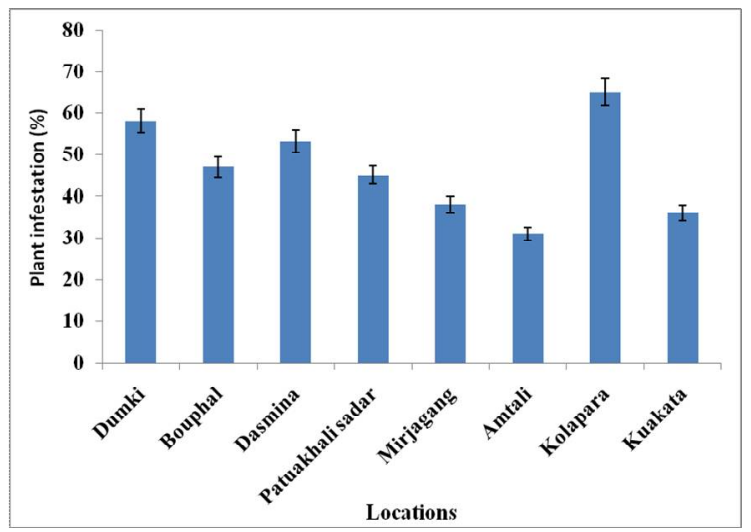

Fig. 3. Mean percentage of plant infestation by $P$. marginatus in eight locations.

Percentage of infested leaves per papaya plant: Percentage of infested leaves per plant by $P$. marginatus among 8 locations are shown in Fig. 4. The highest percent (97\%) infested leaves per plant was recorded at Kolapara followed by Dumki (90\%) while the lowest percent (18\%) was recorded at Amtali followed by Kuakata (21\%).

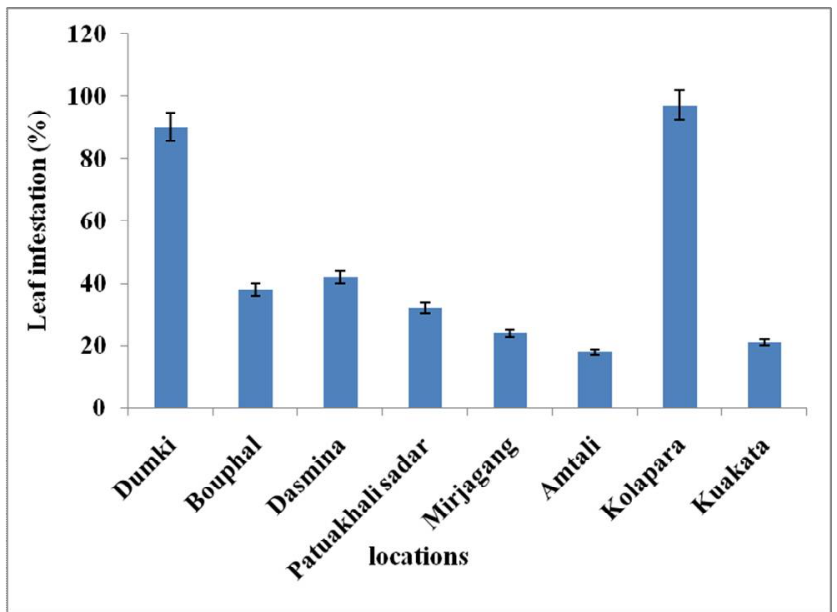

Fig. 4. Mean percentage of infested leaves per papaya plant by $P$. marginatus in eight locations. 
Percentage of infested fruits per papaya plant: The percentage of infested fruit per plant by $P$. marginatus is shown in Figure 5. Among 8 locations, it was observed that the highest percent $(47 \%)$ infested fruit per plant was recorded in Kolapara followed by Dumki (34\%). In contrast. the lowest percent (11\%) was recorded at Amtali followed by Kuakata (13\%), Mirjaganj (15\%) and Patuakhali Sadar (17\%).

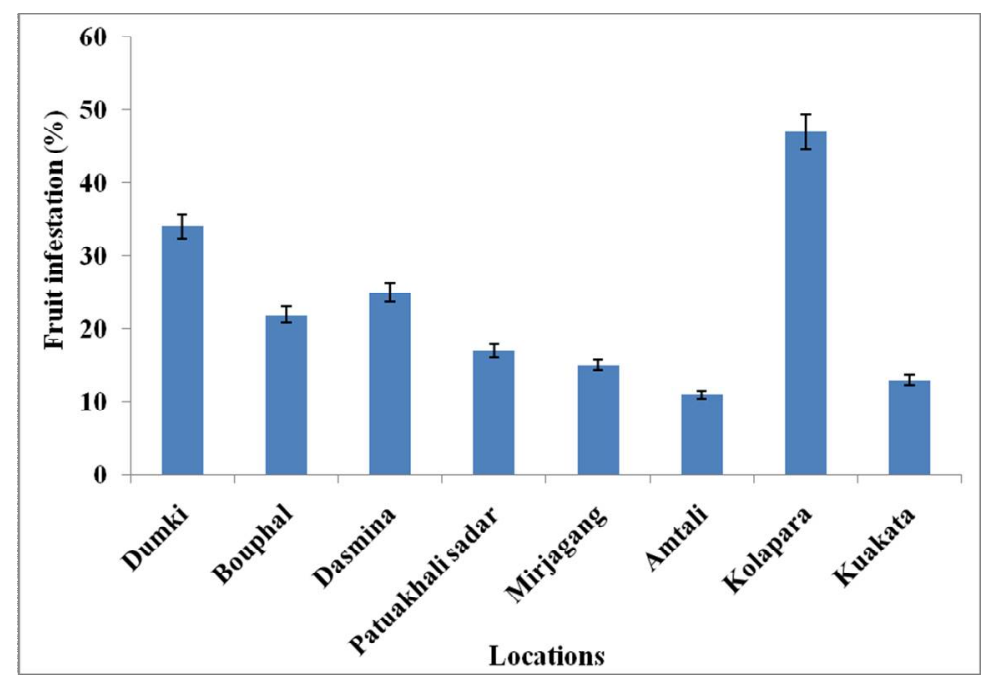

Fig. 5. Mean percentage of infested fruits per papaya plant by $P$. marginatus in eight locations.

Effectiveness of different treatments on mealybug infesting leaf and fruit: The effectiveness of different treatments on mealybug populations infesting leaves and fruits of papaya plants are presented in Table 1 . The lowest number (0.82 mealybugs/leaf) of mealybugs per leaf was found in $\mathrm{T}_{1}$ (Removal of infested leaves with petioles + application of nitro 505EC @ $1 \mathrm{ml} / \mathrm{L}$ of water) treated plants which were significantly different from $\mathrm{T}_{6}$ (Application of voliam flexi 300SC @ $0.5 \mathrm{ml} / \mathrm{L}$ of water) treated plants (2.61 mealybugs/leaf) and $\mathrm{T}_{7}$ (untreated control) (49.49 mealybugs/leaf) but statistically similar to $\mathrm{T}_{2}(2.08), \mathrm{T}_{3}(0.99), \mathrm{T}_{4}(2.36)$ and $\mathrm{T}_{5}(1.08)$ treated plants. The highest percent reduction (98.34\%) of mealybugs population over control was recorded in $\mathrm{T}_{1}$ treated plant followed by $\mathrm{T}_{3}(98.00 \%)$ and $\mathrm{T}_{5}(97.81 \%)$, while the lowest percent reduction was in $\mathrm{T}_{6}(94.73 \%)$ followed by $\mathrm{T}_{4}(95.23 \%)$ and $\mathrm{T}_{2}(95.80 \%)$.

In the case of fruit, the lowest number ( 0.56 mealybugs/fruit) of mealybugs per fruit was found in $\mathrm{T}_{1}$ (Removal of infested leaves with petioles + application of nitro 505EC @ 1 $\mathrm{ml} / \mathrm{L}$ of water) treated plants which were significantly different from $\mathrm{T}_{2}(1.86), \mathrm{T}_{4}(2.04)$, 
$\mathrm{T}_{6}$ (2.16 mealybugs/fruit) treated plants and $\mathrm{T}_{7}$ (untreated control) (33.22 mealybugs/ fruit) but statistically similar to $\mathrm{T}_{3}(0.74)$ and $\mathrm{T}_{5}(0.94)$ treated plants. The highest percent reduction (98.31\%) of mealybugs population over control was recorded in $\mathrm{T}_{1}$ treated plant followed by $\mathrm{T}_{3}(97.77 \%)$ and $\mathrm{T}_{5}(97.17 \%)$, while the lowest percent reduction was in $\mathrm{T}_{6}(93.50 \%)$ followed by $\mathrm{T}_{4}(93.86 \%)$ and $\mathrm{T}_{2}(94.40 \%)$.

Table 1. Effectiveness of different treatments on mealybug populations infesting leaf and fruit of papaya plant.

\begin{tabular}{ccccc}
\hline Treatments & $\begin{array}{c}\text { Number of } \\
\text { mealybugs/leaf }\end{array}$ & $\begin{array}{c}\text { Reduction (\%) } \\
\text { over control }\end{array}$ & $\begin{array}{c}\text { Number of } \\
\text { mealybugs/fruit }\end{array}$ & $\begin{array}{c}\text { Reduction } \\
\text { (\%) over } \\
\text { control }\end{array}$ \\
\hline $\mathrm{T}_{1}$ & $0.82 \mathrm{c}$ & 98.34 & $0.56 \mathrm{~d}$ & 98.31 \\
$\mathrm{~T}_{2}$ & $2.08 \mathrm{bc}$ & 95.80 & $1.86 \mathrm{bc}$ & 94.40 \\
$\mathrm{~T}_{3}$ & $0.99 \mathrm{bc}$ & 98.00 & $0.74 \mathrm{~cd}$ & 97.77 \\
$\mathrm{~T}_{4}$ & $2.36 \mathrm{bc}$ & 95.23 & $2.04 \mathrm{~b}$ & 93.86 \\
$\mathrm{~T}_{5}$ & $1.08 \mathrm{bc}$ & 97.81 & $0.94 \mathrm{bcd}$ & 97.17 \\
$\mathrm{~T}_{6}$ & $2.61 \mathrm{~b}$ & 94.73 & $2.16 \mathrm{~b}$ & 93.50 \\
$\mathrm{~T}_{7}$ & $49.49 \mathrm{a}$ & - & $33.22 \mathrm{a}$ & - \\
$\mathrm{CD}$ values $(5 \%)$ & 1.674 & & 1.261 & \\
$\mathrm{CV}(\%)$ & 11.12 & & 12.01 & \\
\hline
\end{tabular}

Values are an average of three replications. $C D=$ Critical difference value at $5 \%$ level. Value having common letter (s) in a column does not differ significantly $(\mathrm{p}>0.05)$.

$\mathrm{T}_{1}=$ Removal of infested leaves with petioles + application of nitro 505EC @ $1 \mathrm{ml} / \mathrm{L}$ of water, $\mathrm{T}_{2}=$ Application of Nitro 505EC @ $1 \mathrm{ml} / \mathrm{L}$ of water, $\mathrm{T}_{3}=$ Removal of infested leaves with petioles + Biotap plus extra 95EC @ $0.2 \mathrm{~g} / \mathrm{L}$ of water, $\mathrm{T}_{4}=$ Biotap plus extra 95EC @ $0.2 \mathrm{~g} / \mathrm{l}$ of water, $\mathrm{T}_{5}=$ Removal of infested leaves with petioles + application of voliam flexi 300SC @ $0.5 \mathrm{ml} / \mathrm{L}$ of water, $\mathrm{T}_{6}=$ Application of Voliam flexi 300SC @ 0.5 $\mathrm{ml} / \mathrm{L}$ of water and $\mathrm{T}_{7}=$ untreated Control.

The present study's findings are supported by Khan et al. (2014) who stated that the infestation levels of papaya mealybug were varied in different seasons of the year, while high infestation was in March to June. Tairas et al. (2014) observed that the population abundance of $P$. marginatus in the dry season was higher (3226 individuals/plant) than in the rainy season, which counted 285 individuals/plant. The total population of $P$. marginatus was positively correlated with the level of attack on the fruit and leaves of papaya plants. In the dry season, the attack level on the fruit was 32 and $49 \%$ on the 
leaves, while during the rainy season, the attack level was $11 \%$ on fruit and $15 \%$ on leaves. Due to the attack of $P$. marginatus, the leaves become crinkled, yellowish, and dried; the honeydew excreted by the bug and associated black sooty mould formation impairs photosynthesis efficiency of the affected plants. Papaya fruit can be heavily infested with mealybugs, becoming white and essentially inedible (Tanwar et al. 2010). Sandeep and Gurlaz (2016) observed 70\% infestation on different plant parts of papaya. The papaya mealybug inserts its stylet into the epidermis of the leaf or the skin of fruit or stem and feeds on the plant sap. At the same time, it injects a toxic substance into the plant, which results in chlorosis, distortion, stunting, early leaf and fruit fall, the production of honeydew, sooty mould, and possibly the death of the plant (Walker et al. 2003). Infestation of $P$. marginatus appeared like masses of cottony growth on infested plant parts of papaya viz. stem, twigs, leaves, and fruits resulted in yellowing, drying, and stunting of the plants. Honeydew secretion by mealybug resulted in sooty mould development which was observed deposited on all the infested parts of papaya. These damage symptoms were supported by Sultana and Khan (2015). They reported that the percentage of leaf stalk infestation per plant was $88.89 \%$, while the leaf area covered by papaya mealybug colonies was $45 \%$. Colonies of $P$. marginatus excrete honeydew, which coats nearby plant surfaces. Sooty mould developed on honeydew blocks out air and light, impairs photosynthesis and reduces plant productivity. Heavy infestations of thinskinned fruit crops such as papaya can make them unmarketable. P. marginatus causes significant damage to cassava in Central America, and can cause serious damage to papaya, other tropical fruit and ornamentals such as Annona and Hibiscus spp. (Miller and Miller 2002). Sultana et al. (2015) also reported that maximum temperature and relative humidity positively correlated with the mealybug population while rain negatively correlated. Wheel powder applied at the rate $5.0 \mathrm{~g} / \mathrm{L}$ of water at 24,48 , and 72 hours after application provided effective control of the mealybug population in laboratory conditions. Likewise, three doses of Superior 505 EC effective in controlling mealybugs in laboratory conditions.

\section{Conclusion}

The incidence of mealybugs gradually increased with increasing temperature and time. The highest number of papaya mealybugs per leaf and fruit was found in Kolapara and the lowest in Amtali. The highest percentage of plant infestation by P. marginatus was in Kolapara. Considering the lowest number of mealybugs on leaves and fruits and the highest percent reduction of mealybugs over control, out of all treatments, $T_{1}$ (Removal 
of infested leaves with petioles + application of nitro 505EC @ $1 \mathrm{ml} / \mathrm{L}$ of water) was the best management approach and $\mathrm{T}_{3}$ (Removal of infested leaves with petioles + Biotap plus extra 95EC @ $0.2 \mathrm{~g} / \mathrm{L}$ of water) could be applied as $2^{\text {nd }}$ choice for controlling papaya mealybugs.

\section{References}

Bhawane, G.P., S.M. Gaikwad, A.B. Mamlayya and S.R. Aland. 2011. Invasion of papaya mealybug, in Assam. The Bioscan. 6(3): 471-474.

Borror, D.J. and D.M. DeLong. 1954. An Introduction to the Study of Insects. Publ. Holt, Rinehart \& Winston, New York. pp. 1030.

Cham, D., H. Davis, D. Obeng-Ofori and E. Owusu. 2011. Host range of the newly invasion mealybug species Paracoccus marginatus Williams and Granara De Willink (Hemiptera: Pseudococcidae) in two ecological zones of Ghana. Res. Zool. 1(1): 1-7.

Chellanppan, M., L. Lawrence, P. Indhu, T. Cherian, S. Anitha and T. Jimcymaria. 2013. Host range and distribution pattern of papaya mealybug, Paracoccus marginatus Williams and Granara De Willink (Hemiptera: Pseudococcidae) on selected Euphorbiaceae hosts in Kerala. J. Trop. Agric. 51(1-2): 51-59.

Islam, K.S., M.R. Ali, M. A. Hossain, F.M. Aminuzzaman, M.J. Ullah, M.F. Alam, S. Saha and K.M.A.A. Mahamud. 2017. Pest risk analysis of mealybug spp. in Bangladesh. Strengthening Phytosanitary Capacity in Bangladesh Project. Plant Quarantine Wing, DAE, Khamarbari, Farmgate, Dhaka-1205. 28 p.

Khan, M.A.M., M.J.H. Biswas, K.S. Ahmed and S. Sheheli. 2014. Outbreak of Paracoccus marginatus in Bangladesh and its control strategies in the fields. Progress. Agric. 25: 17-22.

Lalitha, N., S.M.V. Kumar, A.K. Saha and S.N. Kumar. 2015. Report of papaya mealybug, Paracoccus marginatus in mulberry in West Brngal. Current Biotica. 9(1): 82-85.

Miller, D.R. and G.L. Miller. 2002. Redescription of Paracoccus marginatus Williams and Granara de Willink (Hemiptera: Coccoidea: Pseudococcidae), including descriptions of the immature stages and adult male. Proc. Entomol. Soc. Wash. 104: 1-23.

Muniappan, R., B.M. Shepard, G.W. Watson, G.R. Carner, G. Sartiami, A. Rauf and M.D. Hmming. 2008. First report of papaya mealybug, Paracoccus marginatus Williams and Granara de Willink (Hemiptera: Coccoidea: Pseudococcidae) in Indonesia and India. J. Agric. Urban Entomol. 25(1): 37-40.

Neuenschwander, P. 2003. Biological control of cassava and mango mealybugs. In Biological Control in IPM Systems in Africa. Neuenschwander, P., Borgemeister, C and Langewald. J. (Editors). CABI Publishing in association with the ACP-EU Technical Centre for Agricultural and Rural Cooperation (CTA) and the Swiss Agency for Development and Cooperation (SDC). pp. 45-59. ISBN: 0-85199-639-6.

Norris, R.F., E.P.C. Chen and M. Kogan. 2003. Concept in Integrated Pest Management. New Jersey, USA: Prentice Hall.

Sakthivel, P., P. Karuppuchamy, Kalyanasundaram and T. Srinivasan. 2012. Host plants of invasive papaya mealybug, Paracoccus marginatus (Williams and Granara de Willink) in Tamil Nadu. Madras Agric. J. 99(7-9): 615-619. 
Sandeep, S. and K. Gurlaz. 2016. Record of papaya mealybug, Paracoccus marginatus Williams and Granara de Willink and its natural enemies on papaya, guava, grapes and plumeria in Punjab. Pest Manage. Hort. Ecosyst. 22(1): 45-50.

Satyanarayana, C., R.K.Y. Babu and M. Manjunatha. 2003. Preliminary studies on botanicals against Maconellicoccus hirsutus (Green). Insect Environ. 9(3): 114- 115.

Schulthess, F., P. Neuenschwander and S. Gounou. 1997. Multi-trophic interactions in cassava, Manihot esculenta, cropping systems in the subhumid tropics of West Africa. Agric. Ecosyst. Environ. 66 (3): 211-222.

Sultana, I., M.M.H. Khan and M.H. Rahman. 2015. Incidence of guava mealy bug, Ferrisia virgata ckll and its management. Bangladesh J. Entomol. 25(2): 13-22.

Sultana, I. and M.M.H. Khan. 2015. Host range, damage extent and morphometrics of mealybug spp. (Hemiptera: Pseudococcidae). Bangladesh J. Entomol. 25(2): 67-75.

Tairas, W., M. Tulung, J. Pelealu and S.J. Rondonuwu. 2014. Study on population abundance of papaya mealybug (Paracoccus marginatus Williams \& Granara de Willink) in the North Minahasa Regency of North Suawesi Province, Indonesia. Int. J. Sci. Eng. Res. 5(3): 961-964.

Tanwar, R. K., P. Jeyakumar, and S. Vennila. 2010. Papaya mealybug and its management strategies. Technical Bulletin 22. National Centre for Integrated Pest Management, New Delhi. 1-20 pp.

Walker, A., M. Hoy and D. Meyerdirk. 2003. "Papaya mealybug, Paracoccus marginatus Williams and Granara de Willink (Hemiptera: Coccoidea: Pseudococcidae)," EENY-302. Featured Creatures. The Entomology and Nematology Department, Florida Cooperative Extension Service, Institute of Food and Agricultural Services, University of Florida, Gainesville, FL, USA. 